\title{
Late Quaternary lake-level changes of Lake El'gygytgyn, NE Siberia
}

\author{
Olaf Juschus ${ }^{\mathrm{a}, *}$, Maksim Pavlov ${ }^{\mathrm{b}}$, Georg Schwamborn ${ }^{\mathrm{c}}$, Frank Preusser ${ }^{\mathrm{d}, 1}$, \\ Grigory Fedorov ${ }^{\mathrm{b}}$, Martin Melles ${ }^{\mathrm{e}}$ \\ a Institute of Applied Geoscience, Technische Universität Berlin, Ackerstraße 76, Sek ACK 1-1, 13355 Berlin, Germany \\ ${ }^{\mathrm{b}}$ Arctic and Antarctic Research Institute, Bering Street, 199397 St. Petersburg, Russia \\ c Alfred Wegener Institute for Polar and Marine Research, Telegrafenberg, 14471 Potsdam, Germany \\ d Institute of Geological Sciences, Universität Bern, Baltzerstrasse 1+3, 3012 Bern, Switzerland \\ e Institute of Geology and Mineralogy, University of Cologne, Zuelpicher Strasse 49a, 50674 Cologne, Germany
}

\section{A R T I C L E I N F O}

\section{Article history:}

Received 12 February 2010

Available online 3 August 2011

\section{Keywords:}

Lake El'gygytgyn

Siberian Arctic

Late Quaternary

Lake-level changes

\begin{abstract}
A B S T R A C T
Lake El'gygytgyn is situated in a 3.6 Ma old impact crater in northeastern Siberia. Presented here is a reconstruction of the Quaternary lake-level history as derived from sediment cores from the southern lake shelf. There, a cliff-like bench $10 \mathrm{~m}$ below the modern water level has been investigated. Deep-water sediments on the shelf indicate high lake levels during a warm Mid-Pleistocene period. One period with low lake level prior to Marine Oxygen Isotope Stage (MIS) 3 has been identified, followed by a period of high lake level (10 $\mathrm{m}$ above present). In the course of MIS 2 the lake level dropped to $-10 \mathrm{~m}$. At the end of MIS 2 the bench was formed and coarse beach sedimentation occurred. Subsequently, the lake level rose rapidly to the Holocene level. Changes in water level are likely linked to climate variability. During relatively temperate periods the lake becomes free of ice in summer. Strong wave actions transport sediment parallel to the coast and towards the outlet, where the material tends to accumulate, resulting in lake level rise. During cold periods the perennial lake ice cover hampers any wave activity and pebble-transport, keeping the outlet open and causing the lake level to drop.
\end{abstract}

(C) 2011 University of Washington. Published by Elsevier Inc. All rights reserved.

\section{Introduction}

Lake El'gygytgyn is located within a meteorite impact crater that formed $3.58 \pm 0.04 \mathrm{Ma}$ ago in Cretaceous volcanic rocks (Layer, 2000; Ispolatov et al., 2004) on the Chukchi Peninsula, NE Siberia (Fig. 1). Although the crater is located in a mountainous region to the north of the Arctic Circle, the side has never been glaciated during the Quaternary (Glushkova and Smirnov, 2005a, 2007). During the past decade its sedimentary fill has become a major focus of paleoclimatological research in the terrestrial Arctic (Brigham-Grette et al., 2007). Seismic surveys conducted during the summers of 2000 and 2003 recorded a total lake sediment succession of 300-420 m thickness above impact breccia (suevite) and brecciated bedrock (Gebhardt et al., 2006; Niessen et al., 2007). This suggests continuous limnic deposition after the impact event, uniquely reflecting the history of the terrestrial Arctic since Pliocene times. In 1998 and 2003, two sediment cores 13 and $16.5 \mathrm{~m}$ in length have been recovered (PG1351 and Lz1024, Fig. 1). The cores revealed continuous limnic deposition in Lake El'gygytgyn throughout the past $300 \mathrm{ka}$ (Forman et al., 2007; Nowaczyk et al., 2007; Juschus et al., 2007), and a very sensitive documentation of the

\footnotetext{
* Corresponding author. Fax: + 492214705149.

E-mail address: olaf.juschus@web.de (O. Juschus).

1 Present address: Department of Physical Geography and Quaternary Geology, Stockholm University, 10691 Stockholm, Sweden.
}

regional climatic and environmental history in the sediment composition of the lake sediments (e.g. Nowaczyk et al., 2002; Melles et al., 2007; Minyuk et al., 2007). A deep drilling campaign within the International Continental Scientific Drilling Program (ICDP) in winter and spring 2009 extracted the complete sediment archive of the lake.

The main objective of this study is reconstructing lake-level changes from sediment properties as found in cores from the southernmost part of Lake El'gygytgyn (cores Lz1027 and Lz1028, Fig. 1). A sequence of different lake-levels is suitable to reflect climatic changes (Harrison et al., 1996) if other forcing like tectonic activity can be excluded (Colman, 1998). During the field campaign in 2003 excellent water translucence allowed identifying a distinct morphological bench, approximately $1-1.5 \mathrm{~m}$ in height (Fig. 2). The bench with a cliff-like character was observed at two neighbouring locations at a water depth of about $10 \mathrm{~m}$, approximately $500 \mathrm{~m}$ north of the southern lake shore. It was traced laterally at both locations for about $20 \mathrm{~m}$.

In order to examine the nature of the bench and its suggested formation during a period with lower lake level two sediment cores were recovered for further sediment analyses. Whereas core Lz1027 was taken "offshore" from the bench, core Lz1028 penetrated the sediment succession, which built up the cliff-like step (Fig. 3). Results of the sediment analyses will improve understanding the lake level history, thus also improving the interpretation of the sediment record of the deep basin. 


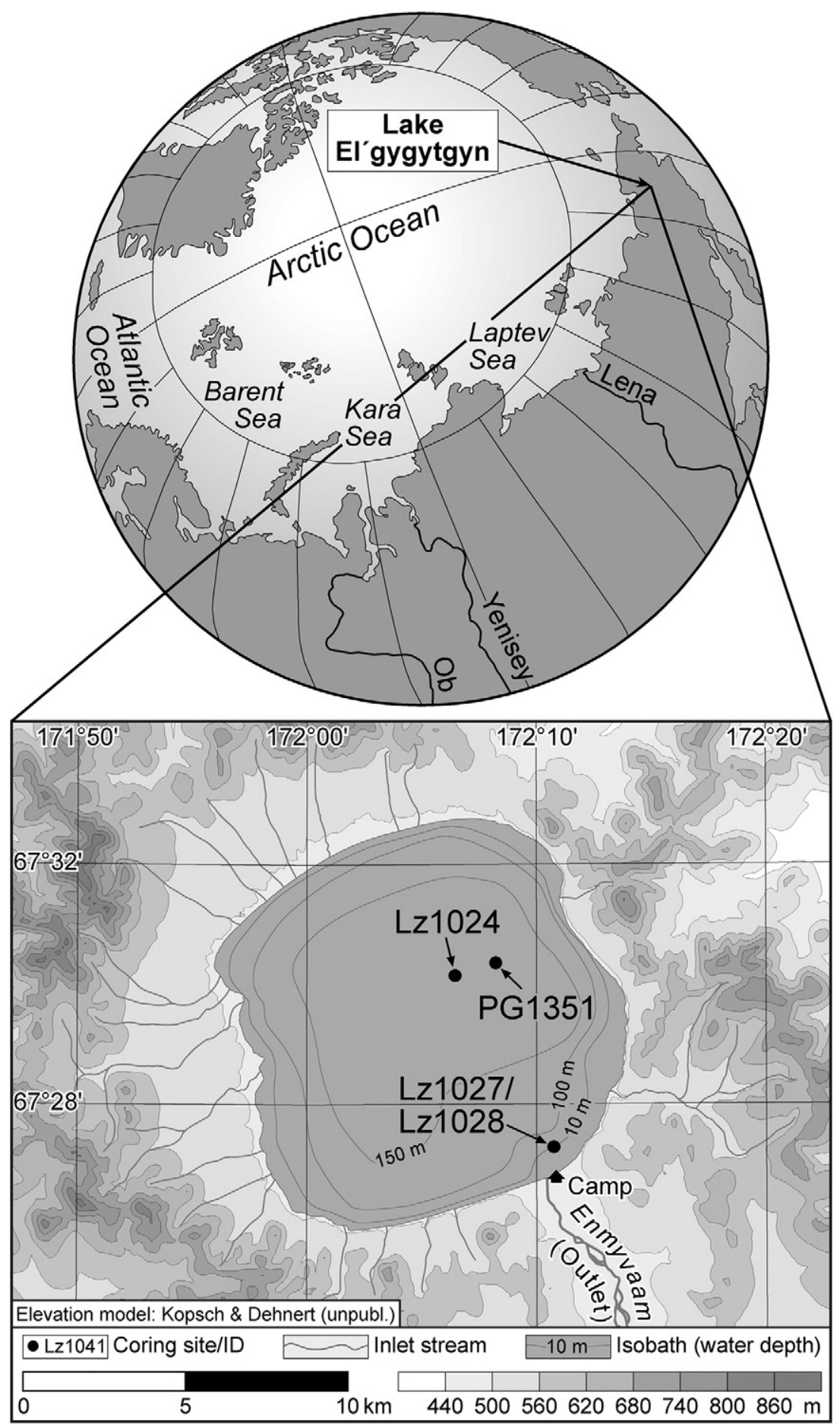

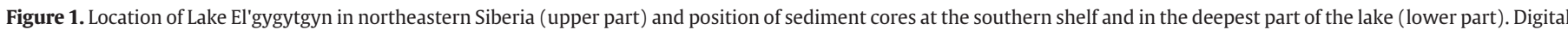
elevation model after Kopsch (2005); lake bathymetry after Belyi (2001).

\section{Site characteristics}

The crater rim, roughly $18 \mathrm{~km}$ in diameter, is at an elevation between 540 and $930 \mathrm{~m}$, but the surface of the lake lies at $492 \mathrm{~m}$ a.s.l. The lake itself has a diameter of about $12 \mathrm{~km}$, a surface area of $110 \mathrm{~km}^{2}$, and a maximum water depth of $170 \mathrm{~m}$. It is cold (app. $3^{\circ} \mathrm{C}$ during summer), monomictic and extremely oligothrophic (Cremer et al., 2005; Nolan and Brigham-Grette, 2007).

The catchment is limited to the crater area $\left(293 \mathrm{~km}^{2}\right)$. About 50 small inlets drain into the lake (Nolan and Brigham-Grette, 2007). The outlet (Enmyvaam River) exits to the south in a broad valley (Fig. 1).
With a width of about $2 \mathrm{~km}$ and less than $2 \mathrm{~m}$ of relief its surface, covered with cobbles, is remarkably flat. The modern river system inside this plain is less than $200 \mathrm{~m}$ wide. It is active only during summer time (Schwamborn et al., 2005).

Due to its position about $100 \mathrm{~km}$ north of the Arctic Circle the lake surface today remains ice-covered for about 9 months of the year. The open water season usually starts during mid July. A stable lake-ice cover is formed again in Late October (Nolan et al., 2003). During glacial periods (MIS 2, 4, 6 and others) the lake is expected to have a perennial ice cover, which led to anoxic conditions at the lake bottom (Nowaczyk et al., 2002; Melles et al., 2007; Asikainen et al., 2007). 


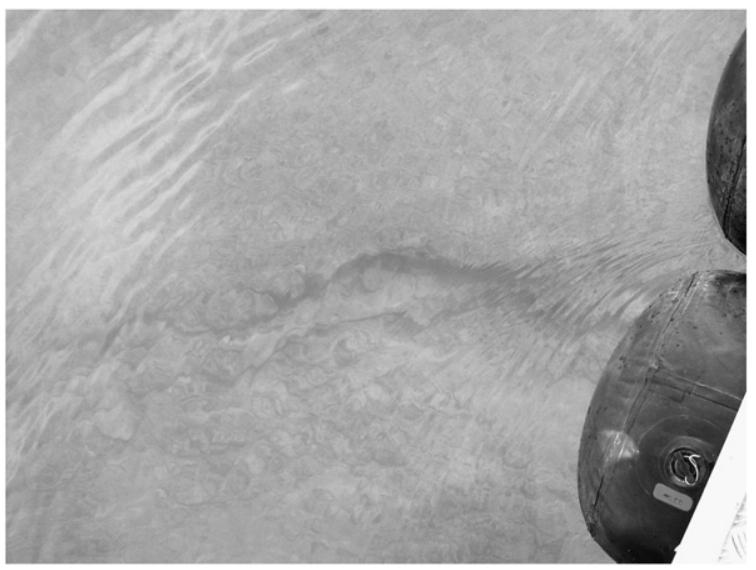

Figure 2. The submerged, cliff-like step on the southern shelf of Lake El'gygytgyn. The picture was taken from the floating platform. In the lower part of the picture the southern, lake-ward side of the bench is visible. Picture by J. Brigham-Grette.

The lake bathymetry is characterised by a comparatively flat, bowl-shaped bottom, extremely steep slopes (up to $30^{\circ}$ ), and a more or less narrow shelf up to $12 \mathrm{~m}$ depth (Fig. 1; Kopsch, 2005). Although its width is usually less than $100 \mathrm{~m}$, it broadens in the southern and south-eastern part of the lake to about $1 \mathrm{~km}$. Here, the shelf surface is covered with a patchwork of rippled sand, gravel and cobbles. While the ripples indicate transportation processes on the respective shelf areas, especially the cobbled patches seem to represent residua of erosion apparently inactive in recent times. Near the inlets the shallows are littered with detrital plant material probably derived during the spring freshet. Apart from that no higher plants were recognised to grow on the lake shelf.

The shore is predominately composed of pebbles and gravels. Strong storms and waves with more than $1 \mathrm{~m}$ height hamper the sedimentation of finer material and led to formation of a distinct pebbly shore bar. In spring 2003, stormy winds pushed lake ice onto the shore to annually modify the bar morphology up to 1 to $2 \mathrm{~m}$ in height. According to the prevailing northerly or southerly wind directions the respective shorelines are most affected by these processes (Nolan and Brigham-Grette, 2007). Drifting ice floats can transport washed-out sediments from inlet creeks across the lake during ice break-up in spring.

\section{Ancient lake levels}

Following earlier work (Obruchev, 1938; Nekrasov, 1963), some recent studies have investigated past lake-level variations of Lake El'gygytgyn (Glushkova and Smirnov, 2007; Gurov et al., 2007; Schwamborn et al., 2008a, 2008b). All of these studies, however, focused on lake-levels higher than the modern level of $492 \mathrm{~m}$ a.s.l. (above sea level).
The uppermost levels, described in the literature and interpreted as lacustrine terraces are situated about 80 and $60 \mathrm{~m}$ above the modern lake level (Nekrasov, 1963; Gurov et al., 2007). According to Gurov et al. (2007) these levels are best preserved in the western and south-western parts of the crater, but they are not commonly confirmed. Glushkova and Smirnov (2005b), in contrast, did not observe prominent rounded pebbles in the area, which would be indicative of fluvial and lacustrine terraces at the respective levels. They suggest a periglacial origin of the deposits found at those highest levels (e.g. solifluction).

The highest terrace level without further questioning is recognised about $40 \mathrm{~m}$ above the modern lake level (Obruchev, 1938; Nekrasov, 1963; Glushkova and Smirnov, 2005b, 2007; Gurov et al., 2007). It is restricted to few remnants in the southern crater area. Indicative for this interpretation is the occurrence of rounded pebbles. The 40 -m-level was mainly formed by abrasion. Only a thin cover of pebbles was deposited, which is now incorporated into slope debris and periglacial deposits. However, the partly eroded and weathered nature of this terrace points to a formation prior to the Late Pleistocene. Glushkova and Smirnov (2007) suggest a Mid-Pleistocene age of the 40-m-level, but without any geochronological control.

The lacustrine terrace 9-11 $\mathrm{m}$ above lake level is widespread at the southern shore of Lake El'gygytgyn (Glushkova and Smirnov, 2007). It differs from the previous level by its fresh appearance and accumulative nature (Glushkova et al., 2005). The outcropping deposits can have a thickness of more than $10 \mathrm{~m}$. They mainly consist of pebbly gravel with occasional sand lenses suggesting formation close to the lake shore. According to palynological analyses the deposition of the terrace formation started during the Karginsky Interstade (Glushkova and Smirnov, 2007), which is thought to be the regional expression of Marine Oxygen Isotope Stage (MIS) 3 between 55 and 24 cal ka BP (Larsen et al., 1999). Sedimentation ceased during the Sartan Stadial (MIS 2).

Evidences for a lake level 3-5 m higher than the present level are described from the northern lake shore. Here, a succession of well preserved pebbly shore-bars occurs, while the southern shore seems to be too steep for the formation of these shore-bars (Glushkova and Smirnov, 2005c). One active and up to three fossil shore-bars are observed. The uppermost raised bar dammed the landward permafrost area and led to sedimentation of periglacial slope deposits containing some organic remains (Schwamborn et al., 2008a, 2008b). According to the age control of Schwamborn et al. (2008a, 2008b), formation of these deposits and, hence, of the oldest, outermost shore-bar started before late-glacial time and has a minimum age of 13.2 to 14.2 cal ka BP. Lake level then dropped about $4 \mathrm{~m}$ and left several pebble bars marking successive Holocene shorelines.

\section{Materials and methods}

Both cores, Lz1027 and Lz1028, were recovered during the expedition in 2003 from a floating platform. Sediment coring was conducted using UWITEC coring equipment. A percussion piston corer was used for proper sampling of the sediments. This corer enables

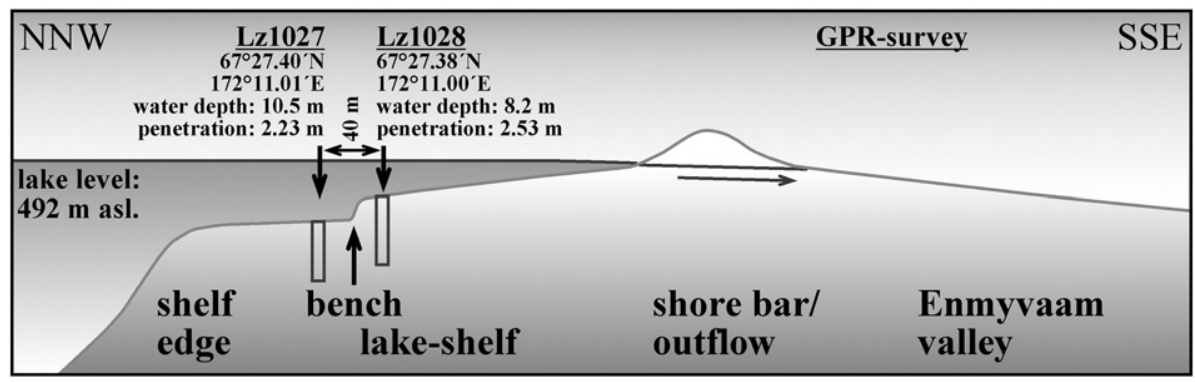

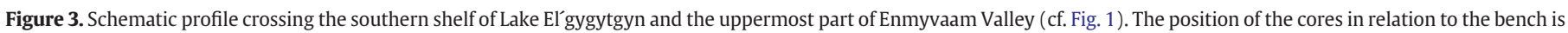
marked. 
sampling of up to $3 \mathrm{~m}$ long sections from defined sediment depths. It encloses a plastic liner with a diameter of $6 \mathrm{~cm}$. The liners were kept cool but above $0^{\circ} \mathrm{C}$ and remained closed until arriving at the laboratories.

Complementary, ground-penetrating radar (GPR) profiles were collected at the very beginning of the Enmyvaam outlet to define the principal stratigraphic setting in this area. A set of 50 and $100-\mathrm{MHz}$ profiles using GPR antennae with $0.5 \mathrm{~m}$ trace spacing was collected in spring time before river activity on the dried-out surface close to the lake. Near surface deposits are composed of pebbly to gravely river bed load. The pore space was air-filled. Velocities of electromagnetic waves in dry sand are commonly around $0.15 \mathrm{~m} \mathrm{~ns}^{-1}$ (Davis and Annan, 1989). This value was used to later convert travel times to depth.

Core description and image scan were immediately carried out after core opening. One core half was subsequently subsampled at intervals of $2 \mathrm{~cm}$. Several samples from Lz1027, at 40, 140 and $190 \mathrm{~cm}$ depth, were directly taken from layers with an obviously increased content of organic detritus. Further on, parts of core Lz1028 were sampled each centimetre for CNS- and grain-size analyses. All subsamples were freeze-dried, and their water contents (in \% of wet bulk sediment) are expressed as the weight difference between wet and dry samples. Grain-size distributions were determined using standardised sieves and a laser particle analyser "Analysette 22" (Fritsch corp., Germany). The contents of total carbon (TC) and total nitrogen (TN) were measured using a CNS-analyzer (Elementar corp., Vario EL III). Total organic carbon (TOC) was analysed with a MetalytCS-1000-S (ELTRA Corp.) in corresponding samples, pretreated using $\mathrm{HCl}(10 \%)$ at a temperature of $80^{\circ} \mathrm{C}$ to remove carbonate.

Sediment age control is based on accelerator mass spectrometry (AMS) ${ }^{14} \mathrm{C}$ dating conducted on humic acids. A total of 14 samples have been dated from cores Lz1027 and Lz1028 at the Leibniz-Laboratory for Radiometric Dating and Isotope Research (Kiel, Germany). All samples, except sample KIA28321, have been taken from organic detritus found within the sediments (Table 1). Due to the origin of the material from a permafrost catchment, a contamination of the sampled material with older plant detritus has to take into account. In that case, the radiocarbon ages are maximum ages. Sample KIA28321 consists of bulk material. No plant detritus was found in the respective sediment section. The exact source of the bulk carbon remains speculative.

Two samples were taken for luminescence dating to compliment the radiocarbon ages (Table 2). For proper sampling the lowermost $10 \mathrm{~cm}$ of each liner were cut from the base. Sample preparation and measurements were carried out at the Luminescence Laboratories of the University of Cologne, Germany. For sample LZE19 coarse grain quartz and feldspar separates have been investigated, while for sample LZE20 polymineral fine-grains have been used. Sample preparation used standard chemical pre-treatments and grain size separation (cf. Preusser et al., 2008). Equivalent dose (De) has been determined using the single aliquots regenerative (SAR) dose protocol (preheat for feldspar: $290^{\circ}$ for $10 \mathrm{~s}, 200^{\circ} \mathrm{C}$ cut-heat; preheat for quartz: $230^{\circ} \mathrm{C}$ for $10 \mathrm{~s}, 160^{\circ} \mathrm{C}$ cut-heat, $250^{\circ} \mathrm{C}$ hot-bleach). Previous studies have found no indication for anomalous fading of the feldspar IRSL signal (Forman et al., 2007; Juschus et al., 2007). Dose rates have been determined ICP-MS (cf. Preusser and Kasper, 2001) and for the problem of sediment moisture determination we refer to Juschus et al. (2007). For sample LZE19 (Lz1027) a present water content of 33\% was determined. The water content after the deposition of the material is estimated to about $50 \%$. Assuming a linear drainage of the sediments, the mean water content since deposition is estimated to about $42 \%$.

\section{Results}

\section{Core $L z 1027$}

\section{Sediment characteristics}

The sediments of core Lz1027, taken "offshore" the cliff-like bench, are almost completely composed of grey, carbonate-free sand, containing variable amounts of fine gravel, silt, and layers as well as lenses of organic detritus (Fig. 4). Coarser grains (up to $3 \mathrm{~cm}$ ) occasionally occur within the core. All of coarser components are more or less rounded. Except the uppermost sample, containing 50\% silt and clay, the content of fine fractions does not exceed $25 \%$. Fluctuations in water content are obviously connected with changes in dominant grain size; silt-rich deposits contain more water than the sandy/gravely sediments.

Most of the clastic material of core Lz1027 is massive or indistinctly bedded. Markers are the changes in grain size, especially the prominent decrease at $22 \mathrm{~cm}$ depth from gravel below to medium/fine sand above. The only evidences for fine lamination are the thin layers enriched in organic detritus. It is worth mentioning that no traces of organic detritus were found within the uppermost $22 \mathrm{~cm}$ of the core. These deposits are built up of homogeneous silty sand and intercalated gravel lenses.

\section{Organic matter}

The amount of organic material within the whole core is low and in general less than 3\%, for half of the samples less than 1\% (Fig. 4). Even layers enriched in organic matter are mainly composed of clastic material, but the amount of organic matter is higher than in the surrounding sediments and sufficient to darken the respective deposits. Usually the organic material is fine but contains fibres, a few millimetres in size. These were likely parts of mosses or herbs.

TOC/TN-ratios are well above 10 , partly above 20 . According to Meyers and Ishiwatari (1995) and Melles et al. (2007) the high ratios at the coring site indicate a supply of predominantly organic matter from the catchment rather than from the lake itself. Additional support for this hypothesis is provided from the slightly higher ratios

Table 1

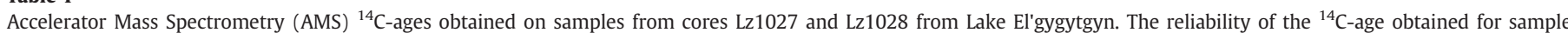
$\mathrm{KIA28321}$ is questionable due to low ${ }^{14} \mathrm{C}$ content.

\begin{tabular}{|c|c|c|c|c|c|}
\hline No. Kiel & Depth $(\mathrm{cm})$ & Core & ${ }^{14} \mathrm{C}$ yr BP & cal yr BP (two sigma) ${ }^{a}$ & Comments \\
\hline KIA28328 & $39-40$ & Lz1027-2 & $11566 \pm 48$ & $13187-13833$ & \\
\hline KIA28327 & $86-87$ & Lz1027-2 & $11980 \pm 55$ & $13653-14295$ & \\
\hline KIA28326 & $104-105$ & Lz1027-2 & $11838 \pm 92$ & $13484-14094$ & \\
\hline KIA28325 & $144-145$ & Lz1027-2 & $11761 \pm 49$ & $13487-14017$ & \\
\hline KIA28324 & $162-163$ & Lz1027-2 & $11987 \pm 56$ & $13656-14298$ & \\
\hline KIA28323 & 194-195 & Lz1027-2 & $12347 \pm 58$ & $14109-15427$ & \\
\hline KIA28322 & $201-202$ & Lz1027-2 & $12378 \pm 54$ & $14123-15414$ & \\
\hline KIA24665 & 195-196 & Lz1028-2 & $\begin{array}{l}38,460+ \\
1170 /-1020\end{array}$ & $42025-43848$ & $\begin{array}{l}\text { low }{ }^{14} \mathrm{C} \text {-content, } \\
\text { one sigma }\end{array}$ \\
\hline KIA28321 & $28.5-30.5$ & Lz1028-2 & $17,476 \pm 510$ & $19478-22136$ & $\begin{array}{l}\text { very low C-content; } \\
\text { bulk sample }\end{array}$ \\
\hline KIA28320 & $164-165$ & Lz1028-2 & $>40,750$ & & critical ${ }^{14} \mathrm{C}$-content \\
\hline
\end{tabular}

\footnotetext{
a Calibration after Stuiver et al. (1998).
} 
Table 2

Overview of dosimetric data and IRSL-ages obtained from cores Lz1027 and Lz1028. Please note that the water content is given in relation to dry sediment weight.

\begin{tabular}{|c|c|c|c|c|c|c|c|c|c|}
\hline Core & Sample-ID & depth $(\mathrm{cm})$ & K (\%) & Th (ppm) & $\mathrm{U}(\mathrm{ppm})$ & Water (\%) & $\mathrm{D}\left(\mathrm{Gy} \mathrm{ka} \mathrm{k}^{-1}\right)$ & De (Gy) & Age (ka) \\
\hline Lz1027 & LZE19F & 204-206 & $2.89 \pm 0.26$ & $5.35 \pm 0.11$ & $1.83 \pm 0.08$ & $42 \pm 4$ & $3.11 \pm 0.25$ & $37.3 \pm 0.9$ & $12.0 \pm 1.0$ \\
\hline Lz1027 & LZE19Q & 204-206 & $2.89 \pm 0.26$ & $5.35 \pm 0.11$ & $1.83 \pm 0.08$ & $42 \pm 4$ & $2.60 \pm 0.23$ & $33.0 \pm 1.6$ & $12.7 \pm 1.3$ \\
\hline Lz1028 & LZE20 & $238-248$ & $2.06 \pm 0.18$ & $6.29 \pm 0.13$ & $2.13 \pm 0.09$ & 42 & $2.57 \pm 0.29$ & $474.6 \pm 19.6$ & $185 \pm 22$ \\
\hline
\end{tabular}

of organic detritus layers when compared with the bulk material of the other samples. For the detritus allochthonous supply is proven by the occurrence of fibres derived from land plants. Additionally, the TOC-contents and the TOC/TN-ratios are likely controlled by the strong decomposition processes which took place in the welloxygenated lake waters.

\section{Age model}

Seven radiocarbon ages are available from various layers rich in organic detritus. For the sampled interval, they indicate a comparably narrow sedimentation period between 15.4 and 13.2 cal ka BP (Table 1). Due to the above mentioned uncertainties, the radiocarbon age is probably a maximum age. The obtained IRSL-ages of $12.0 \pm$ $1.0 \mathrm{ka}$ (feldspar IRSL) and $12.7 \pm 1.3 \mathrm{ka}$ (quartz OSL) are slightly younger (Table 2) but almost overlap within the error frame. All ages indicate that the sediments of core Lz1027 were settled during the final phase of the last Glacial Termination.

\section{Interpretation}

The substrate characteristics allow subdividing core Lz1027 into two different sediment units reflecting different transport energy and, hence, associated different water depths (Fig. 4). The sediment unit boundary is placed at $22 \mathrm{~cm}$ core depth where the prominent grainsize shift occurs.

The coarse material of the lower sediment type, Unit II, is interpreted to represent Late Pleistocene beach or near-shore conditions (Fig. 4). The water depth during the deposition of this unit is assumed to be much shallower than the recent level. Stronger currents, very likely induced by storms and wave action led to the settling of coarse material. Single meteorological events probably caused the deposition of finer sands as well as organic detritus. Furthermore, the obtained ${ }^{14} \mathrm{C}$ ages indicate high sedimentation rates. The rapid burial led to good preservation of organic matter. It is assumed that the lake level rose in the same range than the deposition of the coarse grained sediment section. Otherwise a general change in grain size and other sediment characteristics would be expected.

The upper sediment Unit I (Fig. 4) is interpreted as recent and subrecent (Holocene) shelf sediment deposited at water depths similar to modern conditions. Main characteristic of this sediment type is its residual nature. Strong winds and wave action leads to considerable currents on the shelf hampering continuous settling of pelagic material. On the other side, the shelf currents are usually insufficiently strong for transportation of gravelly to pebbly material. Thus, sandy and silty sedimentation on the shelf is discontinuous and

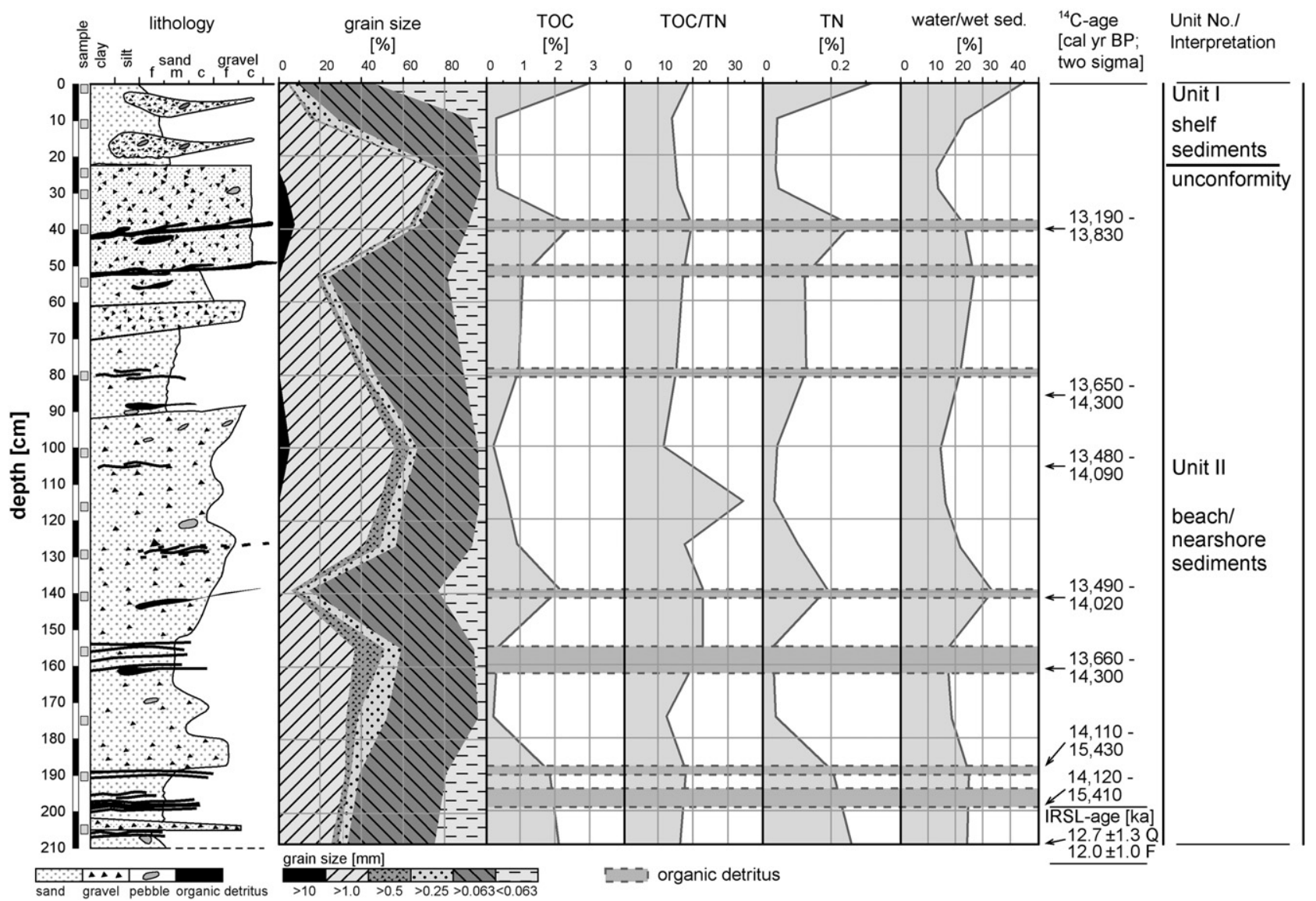

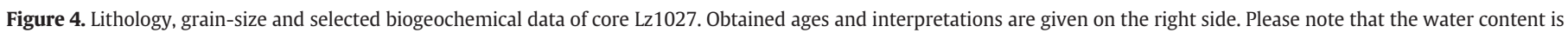
given in relation to wet sediment weight. 
restricted to protected areas. The observed patches with sand ripples on the shelf, inactive during winter times and calm days, as well as the cobbled areas probably without modern sedimentation support this hypothesis. Ice floe transportation during the ice breakup in spring causes very likely the formation of the gravel lenses as observed inside the sandy matrix. Furthermore, the oligothrophic nature and the low sedimentation rate on the shelf lead to an almost complete decomposition of organic matter and the lack of detritus inside the sediments. The maximum TOC-value within the surface sample is explained with the supply of recent organic matter.

\section{Core $L z 1028$}

\section{Sediment characteristics}

Except of the uppermost $30 \mathrm{~cm}$, which are reddish brown, the sediments of core Lz1028 are grey with some changes in brightness. As in core Lz1027 no carbonate is observed. The sediments of core Lz1028 are more variable. The lowermost part, below $229 \mathrm{~cm}$, is built up of fine to medium silt containing some sand (Fig. 5). The silt is dark grey and lacks internal sediment structures except of some sand lenses. A prominent but only $1 \mathrm{~cm}$ thick layer of coarse sand on top of the fine silt marks the limit to the overlying coarser silt bed, which is situated between 228 and about $200 \mathrm{~cm}$. The top of the silty sediments is not sharp; a gradual transition to more sandy deposits occurs between 200 and $195 \mathrm{~cm}$. The greyish colour of the silt brightens to the top. While the mud itself looks more or less massive, some coarser, sandy layers are intercalated. Between 211 and $214 \mathrm{~cm}$ a thick gravelly lens occurs. The gradual shift in grain size between 200 and $195 \mathrm{~cm}$ marks the border to the overlying, mainly sandy section, which dominates up to $31 \mathrm{~cm}$ core depth. In the lower part of this section the material is mostly built up of well-sorted, fine sand. At two positions 194 and between 160 and $165 \mathrm{~cm}$ the greyish sand is darker due to enrichment of organic matter. From $150 \mathrm{~cm}$ upward the deposits coarsen to more medium grained sand but fine sand is still the main component. Usually the sand is massive except some lenses or layers of coarser as well as finer material. A distinct decrease in grain size at $31 \mathrm{~cm}$ core depth marks the border to the uppermost deposits. There, an intercalation of silty, sandy, and gravelly sediments occurs. The uppermost $10 \mathrm{~cm}$ seem to be disturbed during the coring process.

In contrast to Lz1027 there is a correlation between the water content and the grain size only in the uppermost part of core Lz1028. The silty deposits at the base of the core have a water content of less than $20 \%$.

\section{Organic matter}

There is a remarkable low amount of organic material in the core, even lower than in core Lz1027. Except of one sample, which was taken from a detritus layer, the content of organic carbon is around $0.5 \%$ or lower, for the sandy material even less than $0.3 \%$ (Fig. 5 ). Smooth maxima in organic matter were found within the silts in the lower parts of the core. Like in Lz1027 the organic detritus is mostly disperse with some scattered fibres.

The pattern of TOC/TN-ratios is more complex than in core Lz1027. Lower ratios around 10 were measured within the silty deposits at the top and the base of the core while ratios of the sandy deposits, including the detritus are distinctly higher. This pattern can best be explained with changes in supply of the organic material at the site. Whereas within the sands the influence of terrestrial plants is assumed to be higher, the silty deposits probably contain more allochthonous material.

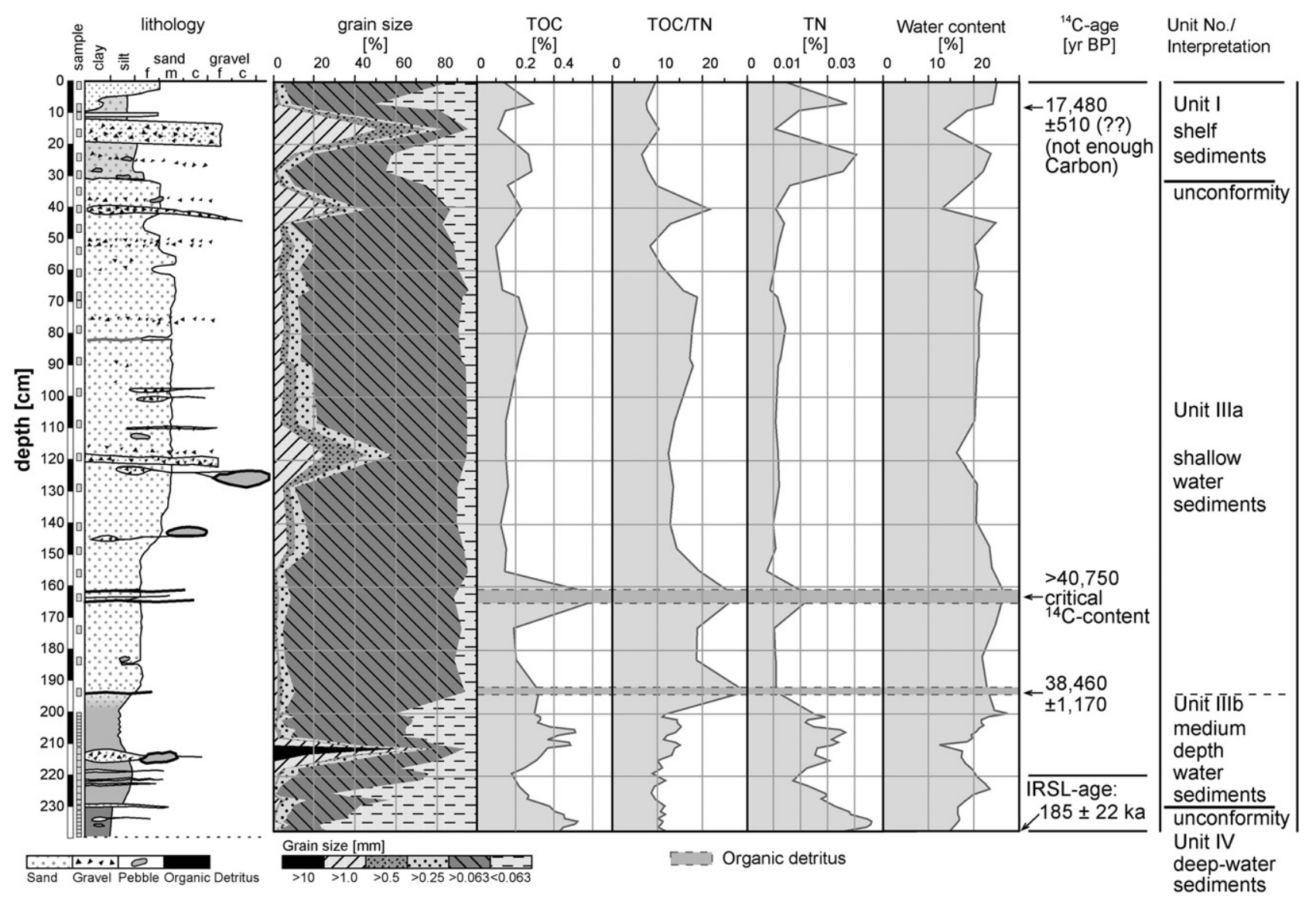

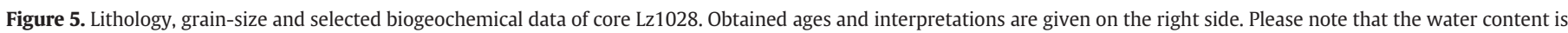
given in relation to wet sediment weight. 


\section{Age model}

The age control is based on three radiocarbon ages (Table 1) and one IRSL-sample (Table 2 ). For the uppermost ${ }^{14} \mathrm{C}$-sample the result is expected to be unreliable (Fig. 5), due to low carbon content of the bulk sample and a questionable source of the bulk carbon. The other samples, taken from organic detritus, turned out with ages close to the upper limit of radiocarbon method. Radiocarbon dating indicates a minimum age of MIS 3 but the samples could be considerably older (cf. Briant et al., 2005). The IRSL age determination of the base unit of core Lz1028 turned out with an age of about $185 \mathrm{ka}$. Similar ages were measured in samples from the lake centre by Juschus et al. (2007), who have demonstrated the reliability of the applied approach for these particular sediments for the last $200 \mathrm{ka}$. Since modelling of the mean water content after deposition (according to Juschus et al., 2007) was not possible on sample LZE20 and as the ages is close the upper dating limit, the obtained IRSL age is regarded to represent a minimum age.

\section{Interpretation}

The two distinct sediment boundaries at 228/229 and $31 \mathrm{~cm}$ depth are interpreted to represent unconformities, probably associated with hiatuses and erosional events. These unconformities give the frame for a subdivision of core Lz1028 into three different sediment units.

The silty deposits at the base of core Lz1028 are the only deep water sediments found in the cores investigated in this study (Unit IV). Significant amounts of silt and clay lack at the southern slopes of the modern lake above a water depth of $35 \mathrm{~m}$ (Dehnert and Juschus, 2008). Nevertheless, they are still coarser than the pelagic sediments from the central basin with a water depth of more than $150 \mathrm{~m}$ (core PG1351, Asikainen et al., 2007) and supposed to build a link between the fine grained sediments from the lake centre and the overlying medium grained deposits. The amount of sand in the sediments of Unit IV is well above $20 \%$ whereas it is mostly less than $4 \%$ in core PG1351. Wind induced currents as well as the transport by ice floating are assumed to be the main transport mechanisms of the sand. Even with an assumed higher lake level the Lz1028 core site is situated comparable close to the lake shore (cf. Fig. 1). Thus, the supply of coarse-grained material from the shore is still possible although the sediments are finer than near-shore deposits. Otherwise, the biogeochemical characteristics of Unit IV-sediments are close to the deep-water sediments of Unit 1 from core PG1351 as described by Melles et al. (2007). The values for TOC and TN are quite similar. Further on, the respective sediments in both cores, Lz1028 and PG1351, are massive or indistinctly stratified. Melles et al. (2007) interpreted the sediments of Unit 1 as deposited under warm climatic conditions. According to this and the result of the IRSL-age determination, the sediments of Unit IV were formed in MidPleistocene times (MIS 7 or older warm stages). The comparable high sediment age and steady water-removal are assumed to be the reason for the low water content of these sediments.

The overlying sediment succession between 228 and $31 \mathrm{~cm}$ depth is assigned to a depositional environment in shallow to mediumdepth waters (sediment Unit III). The occurrence of a more sandy upper and a more silty lower part results in the division into sub-Units IIIa and IIIb. The lack of any unconformities between 31 and $228 \mathrm{~cm}$ gives the argument to keep both subunits under the umbrella of one main sediment unit. The deposition of the lower silty sediments of Unit IIIb requires water conditions deeper than those of the upper, more sandy portions. On the other side, their characteristics exclude deep water conditions. This is supported by the observed sand lenses and the higher amount of sand within the sediment matrix in comparison to the underlying sediments. The upper sandy deposits are associated with shallower waters and, hence, higher transport energy. Nevertheless, the water depth during the respective deposition is assumed to be higher than the present shelf conditions with $8.2 \mathrm{~m}$ depth. This assumption is necessary when explaining the sedimentation of the $1.6 \mathrm{~m}$ thick sediment unit without hiatuses and the residual character of the shelf sediments (Unit I). According to the radiocarbon ages obtained these sediments were formed during an interstadial prior to or during MIS 3. A cold interval with a perennial ice cover is excluded by the comparable coarse grain size of these sediments.

The uppermost $31 \mathrm{~cm}$ are interpreted as Holocene shelf sediments of Unit I although there are some differences in grain-size compared with the respective sediments in core Lz1027. The observed variability of the recent shelf sedimentation is likely the reason of this.

\section{Discussion}

Model of Lake-Level changes as derived from cores Lz1027 and Lz1028

The results presented above allow establishing a model of lakelevel changes of Lake El'gygytgyn for the period covered by the cores (Fig. 6). The oldest information about the lake level is derived from sediment Unit IV. The formation of the respective deep-water sediments in Mid-Pleistocene times requires a lake level, much higher than present (Fig. 6a). The unconformity between Units IV and III was likely caused by one or more erosional events due to low lake levels before the deposition of Unit III-sediments, which started at least 40 ka ago (Fig. 6b). However, the range of the low level is not known. Furthermore, there is no information about the time period, the duration, and the frequency of the erosional event/events in the time between the formation of Units IV and III. The period of MIS 3 or an older but warm period with annual lake ice breakup, was surely a time of higher lake levels than in present times (Fig. 6c). At the site of Lz1028 the water depths were medium. The general upward coarsening of the sediments indicate a general lowering of the lake level during this time. Between the deposition of Unit III and the Holocene shelf sedimentation (Unit I) the second unconformity surface was formed during a period with low lake level, most likely during MIS 2 (Fig. 6d).

The cliff-like bench and, simultaneously, the sediments of Unit II in core Lz1027 were formed as a result of wave action in the younger part of MIS 2. It indicates a lake level directly at the depth of core Lz1027, about $10 \mathrm{~m}$ below the modern level. It has to be taken into account that there are no data about the level in the older part of MIS 2. After the deposition of Unit II the Late Pleistocene and Holocene shelf sediments of Unit I indicate a lake level in the range of the modern level. The low sedimentation rate on the shelf is probably the reason for the conservation of the bench in Holocene times.

\section{Comparison with other records from Lake El'gygytgyn}

Deepwater sediments of Unit IV, which were settled during the Mid-Pleistocene, may have a corresponding shoreline with the $40 \mathrm{~m}$ terrace, which was formed in Middle Pleistocene times as well (according to Glushkova and Smirnov, 2007). But this connection remains speculative, since the exact age of the $40 \mathrm{~m}$-terrace and of the Unit IV-sediments is not defined. The correlation of sediments from Unit III to the $10 \mathrm{~m}$-terrace level (Glushkova and Smirnov, 2007) is possible but cannot finally be confirmed since the age determinations still have uncertainties.

For the development of the lake level during MIS 2 different, partly conflicting results have to be considered. Following Melles et al. (2007) this stage is characterised by cold but rather dry conditions with a perennial lake-ice cover. While Glushkova and Smirnov (2007) postulate a higher lake level at least in the older part of MIS 2, Cherapanova et al. (2007) assume a low lake level during MIS 2. This is based on diatom assemblages almost without benthic diatoms as a result of dry lake shelf areas and a lack of water currents. For the younger part of MIS 2, the beginning of last Glacial Termination, a lower lake level is inferred by Schwamborn et al. (2008a, 2008b) 


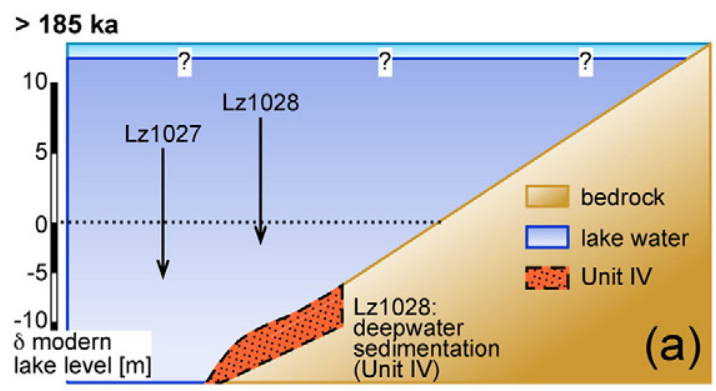

between 185 and prior to $40 \mathrm{ka}$

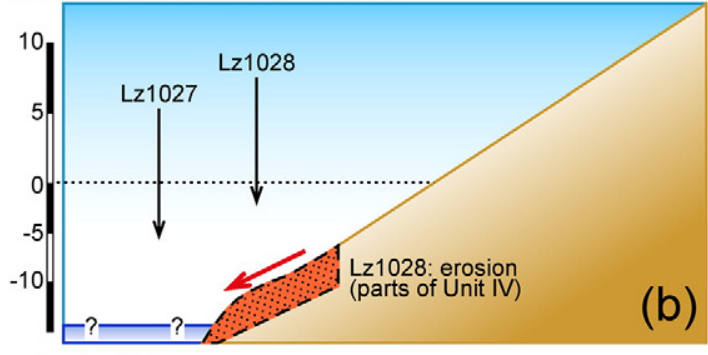

prior to $40 \mathrm{ka}$

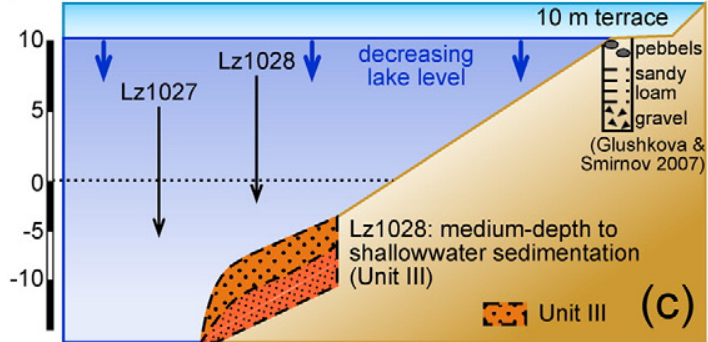

app. 14 ka

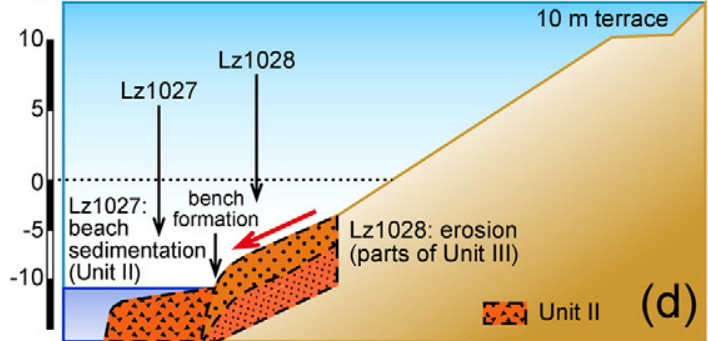

Late Holocene/Present:

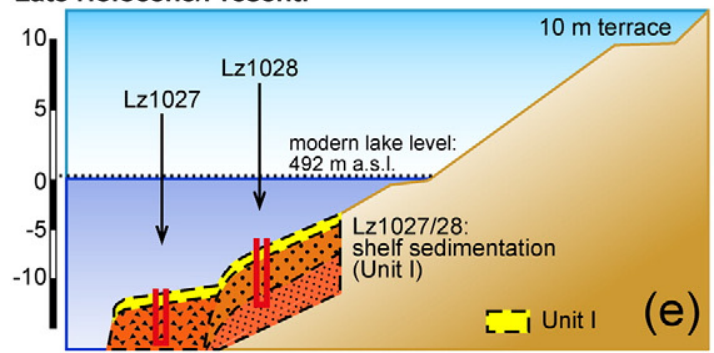

Figure 6. Model of lake-level changes of Lake El'gygytgyn as derived from cores Lz1027 and Lz1028 from the southern lake shelf. The oldest sediments of Unit IV from core Lz1028 indicate a deep-water period prior to $185 \mathrm{ka}$ although the exact range of the level cannot be deduced from the sediments (a). Between $185 \mathrm{ka}$ and prior to $40 \mathrm{ka}$ at least one period with low lake level and subsequent erosion has to assumed (b). The exact lake level is not known for this period as well. During MIS 3 or an older warm stage, the lake level was probably $10 \mathrm{~m}$ higher than in present (c) while it decreased during MIS 2. In late glacial times the lake level was around $10 \mathrm{~m}$ lower than today (d). The bench was formed due to the onset of wave action at this level. Furthermore, beach sediments (Unit II) were deposited at the position of Lz1027. Subsequently, the lake level rose quickly to the Holocene level and the present shelf conditions with limited sedimentation came into being (e). Please note that the profiles are directed from the shelf to the crater rim. based on near-shore studies of ancient shorelines and the results presented in this study. The synthesis that fits most is the assumption of a high lake level $(+10 \mathrm{~m})$ at the beginning of MIS 2 and a lowering to $-10 \mathrm{~m}$ in the course of this stage.

Further on, the coarse beach sedimentation at site Lz1027 in late Pleistocene times requires waves and comparable strong currents around the shore. An open water season has to be assumed for this period. This gives the frame for the onset of the complete lake ice melt during summer in Late Glacial times.

The end of the beach sedimentation at Lz1027 was likely caused by a rising lake level. This is evident by the comparison of the ${ }^{14} \mathrm{C}$ ages obtained from Lz1027 and from the north-eastern part of the lake (Schwamborn et al., 2008a, 2008b). For the upper part of Lz1027 and the lower part of the core from the north-eastern shore the calibrated ${ }^{14} \mathrm{C}$ ages are in the same time frame. This can only be explained with a rapid rise of the lake level from $-10 \mathrm{~m}$ to $+5 \mathrm{~m}$. During the Holocene the lake level tends to gently lower which is obvious on the shore bar systems at the northern shore (Glushkova and Smirnov, 2005c; Schwamborn et al., 2008a, 2008b) and the limited sedimentation on the southern shelf at stations Lz1027 and Lz1028.

\section{The mechanism of lake level changes at Lake El'gygytgyn}

The observed correlation of lake level changes with climate history point out a climatically induced trigger mechanism. This is in concordance with the minor degree of tectonic activities in and around Lake El'gygytgyn both in the past (Niessen et al., 2007) and in the present (Fujita et al., 2002).

The level of the Holocene and modern lake is virtually insensitive to changes in the water balance (precipitation, evaporation). This points out to an indirect relationship between climate and lake-level. El'gygytgyn is a dilute, through-flowing lake, controlled by the level of its outlet, Enmyvaam River. Further on, there is no evidence for increasing salinity and, hence, a closed basin in the paleolimnological record, even during comparable dry periods like MIS 2 (Asikainen et al., 2007; Cherapanova et al., 2007; Melles et al., 2007), although for short periods (less than 1000 years) the lake level might dropped much below $-10 \mathrm{~m}$ during extreme cold and dry intervals.

The GPR survey in the Enmyvaam river bed gravel has been acquired to indicate subground stratigraphy at the southern lake shore. In near-surface permafrost GPR may resolve for example intrapermafrost bedrock (Arcone et al., 1998), peat-sediment contact, delineate massive ice (Moorman et al, 2003), or discrete layers of ice (Schwamborn et al., 2008a, 2008b). The GPR profiles expose a prominent reflector, which undulates at about 80 ns two-way travel time (Fig. 7). The reflector is fairly continuous and can be faintly traced across some parallel lines. The pore space of the loosely packed surficial Enmyvaam river bed gravel was air-filled. Thus, a velocity of the electromagnetic waves in the subground is assumed to be around $0.15 \mathrm{~m} \mathrm{~ns}^{-1}$ as measured for dry sediment (Annan, 2001). This translates into an approximate depth of $5 \mathrm{~m}$ for the reflector. Usually GPR interpretation is backed-up by coring results or exposure studies to reduce ambiguity of interpretation. At our site sediment coring was not feasible in the loose river bed cobbles. Possible interpretations of the reflector's nature may include the contact between river-bed sediments and underlying bedrock. This would point to an ancient erosional level, which nowadays is buried after a water-level rise of the neighbouring lake and a subsequent accumulation of river-bed deposits. This would indicate a minimum level of Enmyvaam River at least $5 \mathrm{~m}$ lower than in present. An outflow would thus have existed even in periods with lower lake levels. Alternations between erosive and accumulative phases of the outlet are considered a main controlmechanism of the lake level.

Another interpretation of the GPR reflector might be that of a contact between an air-filled sediment pack on top of a ground-ice table. Data 


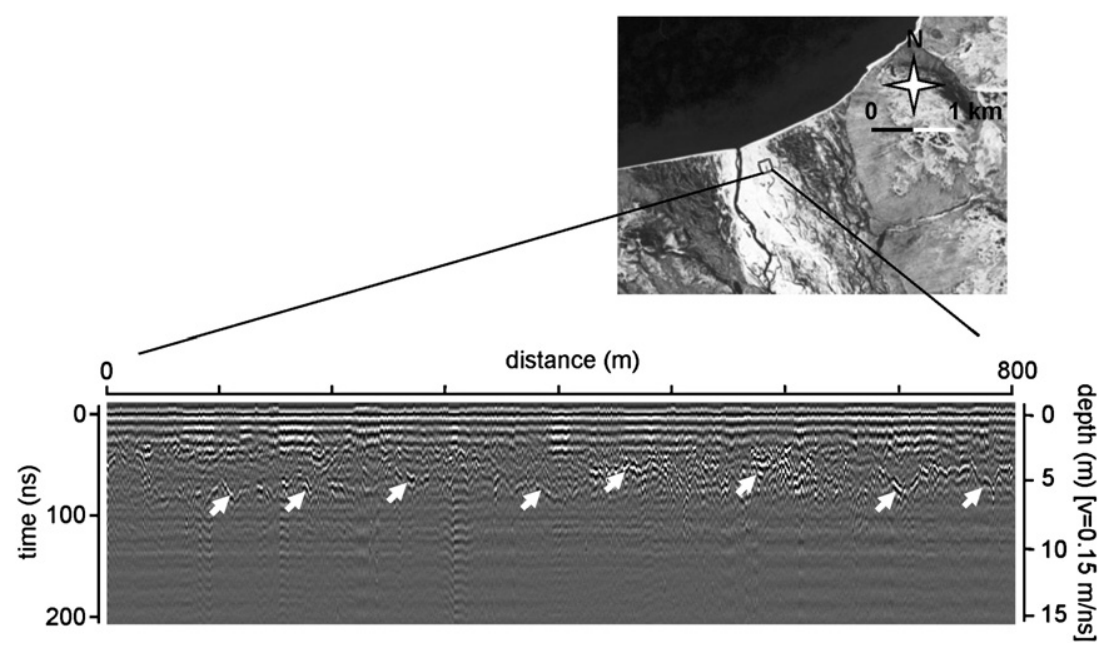

Figure 7. Position of GPR lines in the Enmyvaam outlet river bed. Arrows point at semi-continuous reflector at approximately $5 \mathrm{~m}$ depth.

acquisition took place in late winter, and from field observation it is known that during autumn parallel shore-face transport can block the Enmyvaam river source and the outlet dies out. The river-level decrease might continue into the subground until the ground water level matches the lake level. During winter this should transform into an underground frozen water table after the temperature fall has penetrated into the ground. However, a conclusive remark on the nature of the reflector must remain speculative.

The present morphodynamic processes at the outflow are divided into four seasons. The long-lasting winter season (7-8 months) is tranquil without fluvial and wave action. The early summer season commences with the opening of Enmyvaam River during the spring freshet in late June, i.e. the fluvial activity starts before disintegration of the lake-ice cover in July. This period is dominated by fluvial erosion and a down-cutting of the riverbed (Schwamborn et al., 2005). The late summer season, characterised by fluvial and wave activity, starts in mid of July. Transportation of sand and pebbles parallel to the shoreline supply material to the outlet; the riverbed erosion is decelerated (Fig. 8, upper part). The summer season stops with the closure of Enmyvaam River in autumn (August, September). During the expedition in 2003 the outlet was filled up with pebbles during a strong northerly storm in mid of August. Subsequently, a new shore bar is formed during the autumn phase, characterised by wave action only. The morphodynamic processes at Lake El'gygytgyn cease with the formation of a stable lake ice cover, usually in October (Nolan et al., 2003).

This pattern might be valid for the Holocene and for older, comparable warm stages with annual lake ice breakup. In cold stages the winter season likely lasted longer and the early summer season was the only active phase to discharge the spring freshet. The perennial ice cover led to the absence of wave action. Thus, Enmyvaam River was able to incise into its plain. As a consequence, the lake level tends to drop in cold periods (Fig. 8, lower part). A further drop and the formation of a closed basin is possible for peak cold and dry periods but this interpretation remains speculative. In that scenario the outflow could have been incised when going into or out of peak glacial conditions. With the onset of glacial terminations the lake became free of ice in summer, wave action and pebble transportation commenced and Enmyvaam filled its incision with sediments, which caused the rapid lake-level rise during the initial

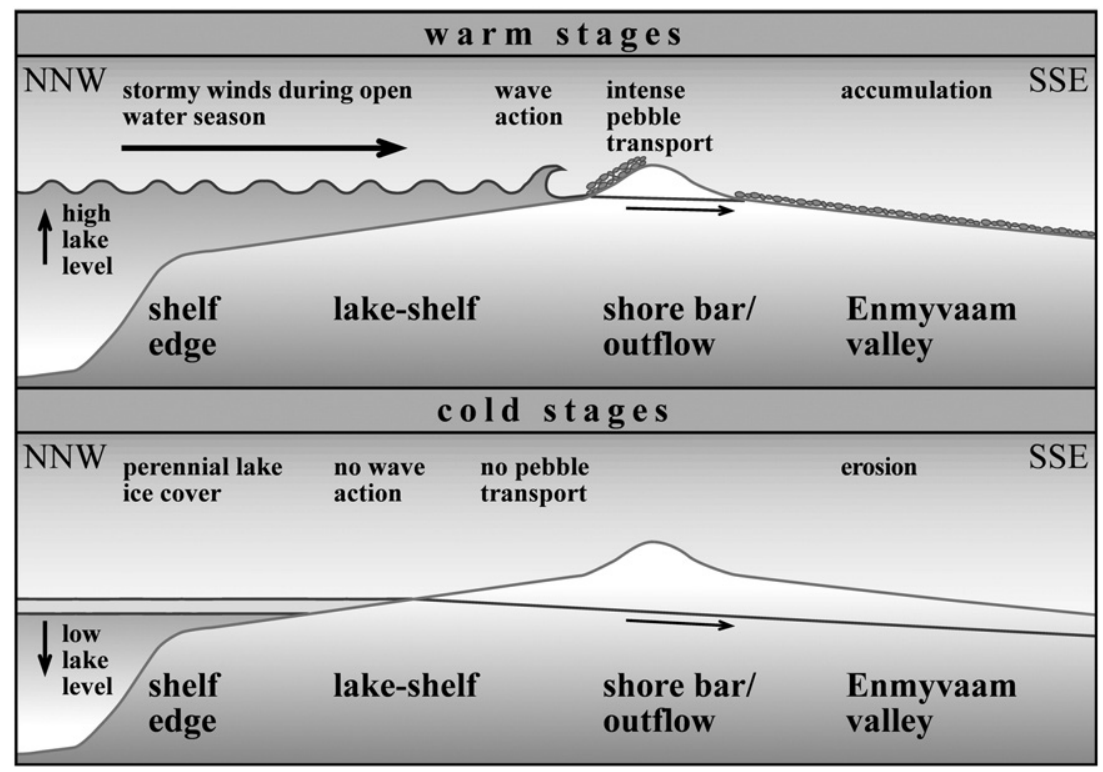

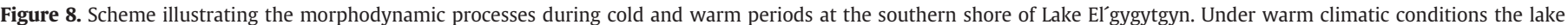

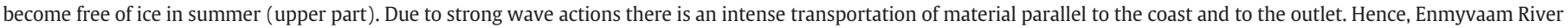

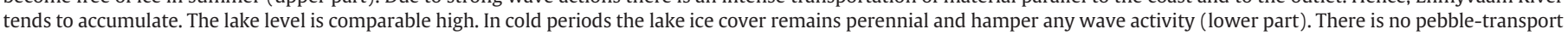
to the outlet and Enmyvaam River is able to erode its own sediments. The lake level tends to drop. 
phases of warm periods. The rise stopped after reaching the level of the broad riverplain. Other factors, like the backward erosion of the river valley from the south seem to be unlikely due to the broad valley and a comparable low river gradient downstream.

The reason of the gentle lake-level drop in Holocene times as described by Schwamborn et al. (2008a, 2008b) is likely connected with the end of the Holocene Thermal Maximum in the early Holocene. Slightly cooler temperatures at the lake in mid Holocene times were detected by Schwamborn et al. (2006). They caused a reduced open-water season and a decreased level of wave action, which allowed Enmyvaam River a minor incision into the riverplain.

The lake-level record of Lake El'gygytgyn in the context of other climate records from Asia and Beringia

To put the presented lake level curve into the context of other records from Beringia and Northern Asia it has to be taken into account that the level of Lake El'gygytgyns is mainly coupled to changes of climate (i.e. temperature) that are linked to changes in geomorphodynamic processes (i.e. shoreface accumulation and erosion). It is almost insensitive to changes in precipitation which makes a direct comparison somewhat complicated. This is especially valid for many lakes on the Tibetan Plateau. There, as summarised by Yu and Ke (2007), lake level fluctuations were mainly induced by changes in precipitation. For MIS 3 they postulate significant higher precipitation than in present times as reflected by higher lake levels in many lakes. For the LGM they described a different pattern with drier conditions to the east of $100^{\circ} \mathrm{E}$ and comparable wet conditions further west. Although the pattern of lakelevel development is partly in phase to that of Lake El'gygytgyn, the different mechanisms of lake-level changes make a direct comparison awkward. Most of the lakes, mentioned by Yu and Ke (2007) are situated inside hydraulically closed basins.

Other conditions prevail at Lake Baikal, a huge tectonically formed but through-flowing basin. The published interpretations about its lake-level fluctuations ranged between two contradicting estimations. Romashkin and Williams (1997) mentioned an extremely huge range of climatically induced lake-level fluctuations of about $450 \mathrm{~m}$. Colman (1998) and Colman et al. (2003), on the other hand, refused the possibility of considerable climatically induced lake-level changes for Lake Baikal. The authors pointed out that the observed relative lakelevel changes were mainly caused by tectonic activity. Apart from that, Urabe et al. (2004) described comparable high lake levels during warm periods. Additionally, they observed a significant lake-level drop in glacial times, which is assumed to be caused by climatically induced changes in the water balance. Recently this has been confirmed by Osipov and Khlystov (2010). The situation at Lake El'gygytgyn, which lacks significant neotectonic activity, is less problematic.

Lake-level changes in northeastern Siberia were also described by Shilo et al. (2004) in Lake Engteri/Kolyma Ridge, approximately $1000 \mathrm{~km}$ to the Southwest of Lake El'gygytgyn. But this lake was formed by mountain glaciers at the Pleistocene-Holocene transition and contains a record of Holocene lake-level changes only.

More profitable seems to be a comparison with the general climate and temperature evolution of the region. For the last $20 \mathrm{ka}$, when a reliable age model is available, the lake-level line fits well with the regional climate. This is valid for both, marine and terrestrial records. Marine studies were carried out in the North-western Pacific, e.g. ODP Sites 882 and 883 (Kiefer et al., 2001; Jaccard et al., 2005) and Marion Dufresne (MD) Site MD01-2416 (Sarnthein et al., 2004), as well as in the Sea of Okhotsk (Nürnberg and Tiedemann, 2004; Harada et al., 2006). Data about lakes in North-eastern Siberia have been published (e.g. Lozhkin et al., 1993; Edwards et al., 2000; Kaufman et al., 2004; Kokorowski et al., 2008; Anderson et al., 2010). Although the pattern is somewhat complicated for the older part of MIS 2 (Harada et al., 2006), for the younger part of MIS 2 as well as for MIS 1 the pattern is unambiguous and in phase with the lake-level record of Lake El'gygytgyn.

\section{Conclusions}

Two sediment cores extracted from the southern shelf of Lake El'gygytgyn provide a detailed insight into the Late Pleistocene and Holocene lake-level history. We infer the following conclusions from sediment analysis and the timing of environmental change (see also Fig. 8):

- High lake levels (present level or higher) prevailed during warm climatic stages with an annual lake ice break up. This is fixed for the Holocene and for two older warm stages. Due to uncertainties of the dating methods the exact age of the older warm stages is not finally recognised.

- The cold period of MIS 2 was a period of a low lake level. During that time the lake was covered by a perennial lake ice blanket. There is evidence for at least one older event with low lake levels, although the age of this event is not known.

- The observed correlation of high lake levels in warm periods and a low lake level during MIS 2 points to a climatically induced trigger mechanism of lake level change.

- The perennial or the seasonal nature of the lake ice cover is seen to play a major role when controlling the onset (or offset) of wave activity and allowing (or preventing) for sediment transport to the outlet and river load aggradation (or river bed incision).

- The coupling of the lake level to the regional climate is linked to changes in temperature, which caused changes in the growth and decay of perennial lake ice.

- The lake level of Lake El'gygytgyn is almost insensitive to changes in precipitation while it reflects the regional temperature history in the course of the Quaternary glacial/interglacial periods.

\section{Acknowledgments}

We thank Julie Brigham-Grette (Amherst, USA), Andreas Dehnert (Zürich, Switzerland), and Pavel Minyuk (Magadan, Russia) for their assistance in coring during the expedition in 2003. Special thanks are due to Stefan Engels (Stockholm, Sweden), Volker Wennrich and Bernd Wagner (Cologne, Germany), Lutz Schirrmeister (Potsdam, Germany) and especially Olga Glushkova (Magadan, Russia) for their comments and assistance.The comments of Dmitry Subetto and Georg Stauch markedly improved the quality of the article. The work was mainly funded by the German Federal Ministry for Education and Research (BMBF; grant no. 03G0586A, B) and the German Research Foundation (DFG, JU 465/2-1).

\section{References}

Anderson, P.M., Lozhkin, A.V., Solomatkina, T.B., Brown, T.A., 2010. Paleoclimatic implications of glacial and postglacial refugia for Pinus pumila in western Beringia. Quaternary Research 73, 269-276.

Annan, A.P., 2001. Ground penetrating radar-workshop notes. Sensors \& Software Inc. 1091 Brevik Place - Mississauga, Ontario - L4W 3R7, Canada.

Arcone, S.A., Lawson, D.E., Delaney, A.J., Strasser, J.C., Strasser, J.D., 1998. Groundpenetrating radar reflection of groundwater and bedrock in an area of discontinuous permafrost. Geophysics 63 (5), 1573-1584.

Asikainen, C.A., Francus, P., Brigham-Grette, J., 2007. Sedimentology, clay mineralogy and grain-size as indicators of $65 \mathrm{ka}$ of climate change from El'gygytgyn Crater Lake, Northeastern Siberia. Journal of Paleolimnology 37, 105-121.

Belyi, V.F., 2001. Structure and formation of the El'gygytgyn Basin (Anadyr Mountains). Geomorphologia 1, 31-41 In Russian.

Briant, R.M., Bateman, M.D., Coope, G.R., Gibbard, Ph.L., 2005. Climatic control on Quaternary fluvial sedimentology of a Fenland Basin river, England. Sedimentology 52, 1397-1423.

Brigham-Grette, J., Melles, M., Minyuk, P., Party, Scientific, 2007. Overview and significance of a $250 \mathrm{ka}$ paleoclimate record from El'gygytgyn Crater Lake, NE Russia. Journal of Paleolimnology 37, 1-16. 
Cherapanova, M.V., Snyder, J.A., Brigham-Grette, J., 2007. Diatom stratigraphy of the last $250 \mathrm{ka}$ at El'gygytgyn Lake, northeast Siberia. Journal of Paleolimnology 37, 155-162.

Colman, S.M., 1998. Water-level changes in Lake Baikal, Siberia: tectonism versus climate. Geology 26 (6), 531-534.

Colman, S.M., Karabanov, E.B., Nelson, C.H., 2003. Quaternary sedimentation and subsidence history of Lake Baikal, Siberia, based on seismic stratigraphy and coring. Journal of Sedimentary Research 73, 941-956.

Cremer, H., Wagner, B., Juschus, O., Melles, M., 2005. A microscopical study of diatom phytoplancton in deep crater Lake El'gygytgyn, Northeast Siberia. Algological Studies 116, 147-169.

Davis, J.L., Annan, A.P., 1989. Ground-penetrating radar for high resolution mapping of soil and rock stratigraphy. Geophysical Prospecting 37, 531-551.

Dehnert, A., Juschus, O., 2008. Rezente sedimentation im Elgygytgyn-See, NE Sibirien, abgeleitet aus der Zusammensetzung von Oberflächensedimenten. Leipzige Geowissenschaften 19, 35-51.

Edwards, M.E., Anderson, P.M., Brubaker, L.B., Ager, T.A., Andreev, A.A., Bigelow, N.H., Cwynar, L.C., Eisner, W.R., Harrison, S.P., Hu, F.-S., Jolly, D., Lozhkin, A.V. MacDonald, G.M., Mock, C.J., Ritchie, J.C., Sher, A.V., Spear, R.W., Williams, J.W., Yu, G., 2000. Pollen-based biomes for Beringia $18,000,6000$ and $0{ }^{14} \mathrm{C}$ yr BP. Journal of Biogeography 27, 521-554.

Forman, S.L., Pierson, J., Gómez, J., 2007. Luminescence geochronology for sediments from Lake El'gygytgyn, northeast Siberia, Russia: constraining the timing of paleoenvironmental events for the past $200 \mathrm{ka}$. Journal of Paleolimnology 37, 77-88.

Fujita, K., Mackey, K.G., McCaleb, R.C., Gubina, L.V., Kovalev, V.N., Imaev, V.S., Smirnov, V.N., 2002. Seismicity of Chukotka, northeastern Russia. In: Miller, L., Grantz, A., Klemperer, S.L. (Eds.), Tectonic Evolution of the Bering Shelf-Chukchi Sea-Arctic Margin and Adjacent Landmasses: Geological Society of America Special Paper, 360 pp. 259-272.

Gebhardt, A.C., Niessen, F., Kopsch, C., 2006. Central uplift structure identified in one of the world's best preserved impact craters. Geology 34 (3), 145-148.

Glushkova, O., Smirnov, V., 2005a. General Geology and Geography. In: Melles, M., Minyuk, P., Brigham-Grette, J., Juschus, O. (Eds.), The Expedition El'gygytgyn Lake 2003 (Siberian Arctic): Reports on Polar and Marine Research, 509, pp. 14-18.

Glushkova, O., Smirnov, V., 2005b. Highest Lake Terraces. In: Melles, M., Minyuk, P. Brigham-Grette, J., Juschus, O. (Eds.), The expedition El'gygytgyn Lake 2003 (Siberian Arctic): Reports on Polar and Marine Research, 509, pp. 85-88.

Glushkova, O., Smirnov, V., 2005c. Coastal Morphology. In: Melles, M., Minyuk, P. Brigham-Grette, J., Juschus, O. (Eds.), The expedition El'gygytgyn Lake 2003 (Siberian Arctic): Reports on Polar and Marine Research, 509, pp. 104-108.

Glushkova, O., Smirnov, V., 2007. Pliocene to Holocene geomorphic evolution and paleogeography of the El'gygytgyn Lake region. Journal of Paleolimnology 37, 37-47.

Glushkova, O., Smirnov, V., Schwamborn, G., Fedorov, G., Kupolov, A., 2005. Terrace 10 m above Lake Level. In: Melles, M., Minyuk, P., Brigham-Grette, J., Juschus, O. (Eds.), The expedition El'gygytgyn Lake 2003 (Siberian Arctic): Reports on Polar and Marine Research, 509, pp. 88-90.

Gurov, E., Koeberl, Ch., Yamnichenko, A., 2007. El'gygytgyn impact crater, Russia: structure, tectonics, and morphology. Meteoritics \& Planetary Science 42, 307-319.

Harada, N., Ahagon, N., Sakamoto, T., Uchida, M., Ikehara, M., Shibata, Y., 2006. Rapid fluctuation of alkenone temperature in the southwestern Okhotsk Sea during the past $120 \mathrm{ky}$. Global and Planetary Change 53, 29-46.

Harrison, S.P., Yu, G., Tarasov, P.E., 1996. Late Quaternary Lake-Level Record from Northern Eurasia. Quaternary Research 45, 138-159.

Ispolatov, V.O., Tikhomirov, P.L., Heizler, M., Cherepanova, I.Yu., 2004. New ${ }^{40} \mathrm{Ar} /{ }^{39} \mathrm{Ar}$ ages of cretaceous continental volcanics from central Chukotka: implications for initiation and duration of volcanism within the northern part of the Okhotsk Chukotka Volcanic Belt (Northeastern Eurasia). Geology 112, 369-377.

Jaccard, S.L., Haug, G.H., Sigman, D.M., Pedersen, T.F., Thierstein, H.R., Röhl, U., 2005. Glacial/interglacial changes in subarctic North Pacific stratification. Science 308 1003-1006.

Juschus, O., Preusser, F., Melles, M., Radtke, U., 2007. Applying SAR-IRSL methodology for dating fine-grained sediments from Lake El'gygytgyn, north-eastern Siberia. Quaternary Geochronology 2, 187-194.

Kaufman, D.S., Ager, T.A., Anderson, N.J., Anderson, P.M., Andrews, J.T., Bartlein, P.J. Brubaker, L.B., Coats, L.L., Cwynar, L.C., Duvall, M.L., Dyke, A.S., Edwards, M.E. Eisner, W.R., Gajewski, K., Geirsdóttir, A., Hu, F.S., Jennings, A.E., Kaplan, M.R., Kerwin, M.W., Lozhkin, A.V., MacDonald, G.M., Miller, G.H., Mock, C.J., Oswald W.W., Otto-Bliesner, B.L., Porinchu, D.F., Rühland, K., Smol, J.P., Steig, E.J., Wolfe, B.B., 2004. Holocene thermal maximum in the western Arctic $\left(0-180^{\circ} \mathrm{W}\right)$. Quaternary Science Reviews 23, 529-560.

Kiefer, T., Sarnthein, M., Erlenkeuser, H., Grootes, P.M., Roberts, A.P., 2001. North Pacific response to millennial-scale changes in ocean circulation over the last $60 \mathrm{kyr}$. Paleoceanography 16, 179-189.

Kokorowski, H.D., Anderson, P.M., Sletten, R.S., Lozhkin, A.V., Brown, T.A., 2008. Late glacial and early Holocene climatic changes based on a multiproxy lacustrine sediment record from Northeast Siberia. Arctic, Antarctic, and Alpine Research 40, 497-505.

Kopsch, C., 2005. Bathymetric Measurements. In: Melles, M., Minyuk, P., BrighamGrette, J., Juschus, O. (Eds.), The expedition El'gygytgyn Lake 2003 (Siberian Arctic): Reports on Polar and Marine Research, 509, pp. 129-131.
Larsen, E., Funder, S., Thiede, J., 1999. Late Quaternary history of northern Russia and adjacent shelves-a synopsis. Boreas 28, 6-11.

Layer, P.W., 2000. Argon-40/argon-39 age of the El'gygytgyn impact event, Chukotka, Russia. Meteoritics \& Planetary Science 35, 591-599.

Lozhkin, A.V., Anderson, P.M., Eisner, W.R., Ravako, L.G., Hopkins, D.M., Brubaker, L.B., Colinvaux, P.A., Miller, M.C., 1993. Late Quaternary Lacustrine Pollen Records from Southwestern Beringia. Quaternary Research 39, 314-324.

Melles, M., Brigham-Grette, J., Glushkova, O.Yu., Minyuk, P.S., Nowaczyk, N.R., Hubberten, H.-W., 2007. Sedimentary geochemistry of a pilot core from Lake El' gygytgyn-a sensitive record of climate variability in the East Siberian Arctic during the past three climate cycles. Journal of Paleolimnology 37, 89-104.

Meyers, P.A., Ishiwatari, R., 1995. Organic matter accumulation records in lake sediments. In: Lerman, A., Imboden, D., Gat, J. (Eds.), Physics and chemistry of lakes, pp. 279-328.

Minyuk, P.S., Brigham-Grette, J., Melles, M., Borkhodoev, V.Ya., Glushkova, O.Y., 2007. Inorganic geochemistry of El'gygytgyn Lake sediments (northeastern Russia) as an indicator of paleoclimatic change for the last $250 \mathrm{kyr}$. Journal of Paleolimnology 37, $123-133$

Moorman, B.J., Robinson, S.D., Burgess, M.M., 2003. Imaging periglacial conditions with ground-penetrating radar. Permafrost and Periglacial Processes 14, 319-329.

Nekrasov, I.A., 1963. About the origin and history of the El'gygytgyn Lake basin. Geologiya i Geophysika 1, 47-59 In Russian.

Niessen, F., Gebhardt, A.C., Kopsch, C., Wagner, B., 2007. Seismic investigation of the $\mathrm{El}^{\text {' }}$ gygytgyn impact crater lake (Central Chukotka, NE Siberia): preliminary results. Journal of Paleolimnology 37, 49-63.

Nolan, M., Brigham-Grette, J., 2007. Basic hydrology, limnology, and meteorology of modern Lake El'gygytgyn, Siberia. Journal of Paleolimnology 37, 17-35.

Nolan, M., Liston, G., Prokein, P., Brigham-Grette, J., Sharpton, V.L., Huntzinger, R., 2003. Analysis of lake ice dynamics and morphology on Lake El'gygytgyn, NE Siberia, using synthetic aperture radar (SAR) and Landsat. Journal of Geophysical Research 108 (D2), 8162.

Nowaczyk, N.R., Minyuk, P., Melles, M., Brigham-Grette, J., Glushkova, O.Y., Nolan, M., Lozhkin, A.V., Stetsenko, T.V., Andersen, P.M., Forman, S.L., 2002. Magnetostratigraphic results from impact crater Lake El'gygytgyn, northeastern Siberia: a $300 \mathrm{kyr}$ long high-resolution terrestrial palaeoclimatic record from the Arctic. Geophysical Journal International 150, 109-126.

Nowaczyk, N.R., Melles, M., Minyuk, P.S., 2007. A revised age model for core PG1351 from Lake El'gygytgyn, Chukotka, based on magnetic susceptibility variations tuned to northern hemisphere insolation variations. Journal of Paleolimnology 37, $65-76$.

Nürnberg, D., Tiedemann, R., 2004. Environmental change in the Sea of Okhotsk during the last 1.1 million years. Paleoceanography 19. doi:10.1029/2004PA001023.

Obruchev, S.V., 1938. The Chaun Bay area: geological and orohydrographic description. Trudy Arckticheskogo Instituta 112, 5-136 In Russian.

Osipov, E.Y., Khlystov, O.M., 2010. Glaciers and meltwater flux to Lake Baikal during the Last Glacial Maximum. Palaeogeography, Palaeoclimatology, Palaeoecology 294, 4-15.

Preusser, F., Kasper, H.U., 2001. Comparison of dose rate determination using highresolution gamma spectrometry and inductively coupled plasma-mass spectrometry. Ancient TL 19, 19-23.

Preusser, F., Degering, D., Fuchs, M., Hilgers, A., Kadereit, A., Klasen, N., Krbetschek, M., Richter, D., Spencer, J., 2008. Luminescence dating: basics, methods and applications. E\&G Quaternary Science Journal 57, 95-149.

Romashkin, P.A., Williams, D.F., 1997. Sedimentation history of the Selenga Delta, Lake Baikal: simulation and interpretation. Journal of Paleolimnology 18, 181-188.

Sarnthein, M., Gebhardt, H., Kiefer, T., Kucera, M., Cook, M., Erlenkeuser, H., 2004. Mid Holocene origin of the sea-surface salinity low in the subarctic North Pacific. Quaternary Science Reviews 23, 2089-2099.

Schwamborn, G., Juschus, O., Fedorov, G., Kupolov, A., Glushkova, O., Smirnov, V., 2005. Fluvial Supply and Export. In: Melles, M., Minyuk, P., Brigham-Grette, J., Juschus, O. (Eds.), The expedition El'gygytgyn Lake 2003 (Siberian Arctic): Reports on Polar and Marine Research, 509, pp. 44-52.

Schwamborn, G., Meyer, H., Fedorov, G., Schirrmeister, L., Hubberten, H.-W., 2006. Ground ice and slope sediments archiving late Quaternary paleoenvironment and paleoclimate signals at the margins of El'gygytgyn Impact Crater, NE Siberia. Quaternary Research 66, 259-272.

Schwamborn, G., Fedorov, G., Schirrmeister, L., Meyer, H., Hubberten, H.-W., 2008a. Periglacial sediment variations controlled by late Quaternary climate and lake level change at Elgygytgyn Crater, Arctic Siberia. Boreas 37, 55-65.

Schwamborn, G., Heinzel, J., Schirrmeister, L., 2008b. Internal characteristics of icemarginal sediments deduced from georadar profiling and sediment properties (Brogger Peninsula, Svalbard). Geomorphology 95, 74-83.

Shilo, N.A., Anderson, P.M., Brown, T.A., Lozhkin, A.V., Pakhomov, A.Y., Solomatkina, T.B., 2004. First Data on Lake Level Changes in Northeastern Siberia during the Postglacial Time. Doklady Akademii Nauk 399A, 1249-1251.

Stuiver, M., Reimer, P.J., Bard, E., Beck, J.W., Burr, G.S., Hughen, K.A., Kromer, B., McCormac, G., Van der Plicht, J., Spurk, M., 1998. INTCAL98 radiocarbon age calibration, 24,000-0 cal BP. Radiocarbon 40 (3), 1041-1083.

Urabe, A., Tateishi, M., Inouchi, Y., Matsuoka, H., Inoue, T., Dmytriev, A., Khlystov, O.M. 2004. Lake-level changes during the past 100,000 years at Lake Baikal, southern Siberia. Quaternary Research 62, 214-222.

Yu, G., Ke, X., 2007. Lake level studies | Asia. In: Elias, S.A. (Ed.), Encyclopedia of Quaternary Science, pp. 1343-1359. 